\title{
Occurrence of self reported hand eczema in Swedish bakers
}

\author{
Jonas Brisman, Birgitta Meding, Bengt Järvholm
}

Institute of Internal Medicine, Section of Occupational Medicine J Brisman

B Järvholm

Department of Respiratory Medicine and Allergology, Göteborg University, Göteborg, Sweden

J Brisman

Department of Occupational Health, National Institute för Working Life, Solna, Sweden

B Meding

Department of Occupational and Environmental

Dermatology, Karolinska Hospital, Stockholm

B Meding

Department of Occupational and Environmental Medicine, Umeå University, Sweden B Järvholm

Correspondence to: Dr J Brisman, Department of Occupational Medicine, $\mathrm{St}$

Sigfridsgatan 85 B, S-412 66 Göteborg, Sweden.

Telephone 0046313354871 ; fax 0046 31409728; email jonas.brisman@ymk.gu.se

Accepted 10 July 1998

\begin{abstract}
Objectives-To estimate the risk of bakers developing hand eczema. The importance of atopy was studied as well as change of job due to hand eczema.

Methods-A retrospective cohort study was performed among bakers trained in Swedish trade schools in 1961-89 $(n=2923)$. School referents followed other programmes $(n=1258)$; population controls were randomly selected from the general population $(n=1258)$. A questionnaire on self reported hand eczema, year of onset of hand eczema, change of work due to hand eczema, childhood eczema, family atopy, and work history was posted to all participants.

Results-The incidence of hand eczema among male controls was 4.4-5.4 cases/ 1000 person-years compared with 16.7 for bakery work. The corresponding figures for women were 11.3-14.1 compared with 34.4. The relative risk for male bakers was 3.5 (95\% confidence interval (95\% CI) 2.8 to 4.5 ) and for female bakers 2.8 (2.2 to 3.6). Skin atopy increased the incidence about threefold and a synergistic effect of atopy and exposure was indicated. Also, bakers had changed job significantly more often than controls.

Conclusions-Swedish bakers, mainly working during the 1970 s and 1980 s, have about a threefold increased risk of hand eczema. There seems to be a synergistic effect of atopy and occupational exposure. (Occup Environ Med 1998;55:750-754)
\end{abstract}

Keywords: bakers; epidemiology; hand eczema

Work related skin symptoms in bakers are reported in the scientific literature. ${ }^{1}$ The work entails heavy skin exposure of the hands and lower arms mainly to flour and moisture. This can cause skin irritation, contact urticaria, ${ }^{2}$ and protein dermatitis. ${ }^{3}$ Contact allergy-for example, to flour additives as antioxidants, spices and flavouring agents-is also reported. ${ }^{45}$

Risk estimates of occupational skin diseases in bakers are sparse. In the Swedish Information System on Occupational Injuries bakers report occupational skin disease four times more often than the average (Börje Bengtsson, National Board of Occupational Safety and Health, Sweden, personal communication, 1997). Tacke et al calculated incidences of occupational skin disease in bakers from the occupational diseases register in North Bavaria. ${ }^{6}$ They found 4.9 cases per 1000 bakers a year in male bakers and 12.0 in female bakers during a 3 year period 1990-3.

Several studies have indicated that bakers with atopy have a higher risk of occupational skin disease. ${ }^{78}$ Tacke et al reported that about $60 \%$ of bakers with occupational skin disease had atopic skin diathesis, and about $40 \%$ respiratory atopy. ${ }^{6}$

Baking is mainly a manual job and the baker is dependent on intact skin on the hands, so bakers with work related skin symptoms are likely to change job. In a study of hand eczema in Göteborg, Sweden, during the 1980s, it was estimated that $11 \%$ of the bakers had changed occupation because of hand eczema. ${ }^{9}$

The objective of the present investigation was to estimate the prevalence and incidence of hand eczema in bakers. The importance of atopy was also studied as well as change of job due to hand eczema.

\section{Materials and methods}

STUDY DESIGN AND SUBJECTS

The design is a retrospective cohort study with a self administered postal questionnaire. The subjects comprised all people born 1943-72 who had graduated from bakery classes in Swedish trade schools from 1961 to 1989 according to school records. These people usually followed the bakery programme for two years, beginning at the age of 16 . In this way 2986 people, trained to become bakers, were identified.

Two control groups were used in the study. One group (school controls) comprised people born between 1943 and 1972, who went to the same trade schools, at the same time as the bakers, but followed another programme. They were mostly trained in other trades of the food processing industry such as butchers, cooks, or brewery or dairy workers. For every 10 bakers, four controls from the same school and year were selected at random. The total number of school controls was 1290 .

Ninety five bakers and school controls were not found in the population register in 1992 and were excluded from the study. Of these, 12 were dead, 14 had emigrated, and three were changing address at the time of the study. The register was not allowed to give the addresses of another three people, and 63 people were not located in the register, probably because of changed social security numbers or emigration without notifying the authorities. After these exclusions 2923 bakers and 1258 school controls remained.

A second control group (population controls) was selected at random from the Swedish population register, stratified for sex and 
Table 1 Cumulative and 1 year period prevalences (\%) of self reported hand eczema and the proportion (\%) of subjects who reported childhood eczema and change of job due to hand eczema in bakers and controls

\begin{tabular}{|c|c|c|c|c|}
\hline & \multicolumn{2}{|c|}{ Former student bakers } & \multirow{3}{*}{$\begin{array}{l}\text { School } \\
\text { controls } \\
(n=931)\end{array}$} & \multirow{3}{*}{$\begin{array}{l}\text { Population } \\
\text { controls } \\
(n=930)\end{array}$} \\
\hline & \multicolumn{2}{|c|}{ Ever worked as baker } & & \\
\hline & $\begin{array}{l}\text { Yes } \\
(n=1644)\end{array}$ & $\begin{array}{l}\text { No } \\
(n=558)\end{array}$ & & \\
\hline \multicolumn{5}{|c|}{$\begin{array}{l}\text { Cumulative prevalence of hand eczema: } \\
\geqslant 18 \text { y at onset: }\end{array}$} \\
\hline Men & 15.0 & $8.0^{\star \star}$ & $8.2^{\star \star}$ & $6.8^{\star \star \star}$ \\
\hline Women & 20.3 & $12.9^{\star \star}$ & $15.1^{\star}$ & $12.1^{\star \star}$ \\
\hline \multicolumn{5}{|c|}{$\leqslant 15 \mathrm{y}$ at onset: } \\
\hline Men & 3.0 & 3.9 & 2.5 & 4.5 \\
\hline Women & 4.1 & 3.5 & 3.5 & 5.4 \\
\hline \multicolumn{5}{|c|}{$1 \mathrm{y}$ period prevalence of hand eczema: } \\
\hline Men & 8.2 & $4.3^{\star}$ & 7.5 & 7.5 \\
\hline Women & 15.0 & 12.7 & 13.9 & $9.4^{\star}$ \\
\hline \multicolumn{5}{|c|}{ History of childhood eczema: } \\
\hline Men & 11.0 & 11.1 & 11.0 & 12.7 \\
\hline Women & 16.8 & 16.6 & 16.1 & 20.5 \\
\hline \multicolumn{5}{|c|}{ Changed job due to hand eczema: } \\
\hline Men & 5.6 & 3.7 & $2.3^{\star \star}$ & $2.1^{\star \star}$ \\
\hline Women & 7.4 & 5.3 & 6.4 & $3.1^{\star \star}$ \\
\hline
\end{tabular}

${ }^{\star} \mathrm{p}<0.05 ;{ }^{\star \star} \mathrm{p}<0.01 ;{ }^{\star \star \star} \mathrm{p}<0.001 v$ former student bakers who had worked as bakers.

10-year birth group. This comprised 1258 people.

The study was approved by the committee of ethics of Göteborg University and by the Data Inspectorate.

\section{QUESTIONNAIRE}

A self administered questionnaire was posted to all participants in late 1992 . The question about eczema (question 13 (Q13)) was: "Do you have or have you had hand eczema?" If this question was answered yes the following questions were: Q14A "How old were you when the hand eczema started?"; Q14B "Have you had hand eczema at any occasion in the past 12 months?". Hand eczema was defined as a positive answer to question Q13. The question about change of work was: Q20C "Have you ever changed job due to hand eczema?".

There were two questions on history of skin atopy: Q19 "Did you have childhood eczema?" and Q21C "Have any of your parents or siblings suffered from atopic eczema?". Questions on respiratory atopic history were: Q11A "Do you have or have you had hay fever?"; Q21A "Have any of your parents or siblings suffered from asthma? ", or Q21B "hay fever?".

The questionnaire also contained information on occupational history and respiratory symptoms. The results on occurrence of asthma have been published elsewhere. ${ }^{10}$

A total of 5439 questionnaires were sent out. The response rates after two reminders were: former baker students 2226/2923 (76.2\%), school controls $931 / 1258(74.0 \%)$, population controls 930/1258 (73.9\%).

RELIABILITY

A second, identical questionnaire was posted to 200 randomly selected people who had answered the first questionnaire without any reminder. The second questionnaire was sent out 5 months after the first one. The response rate was $73 \%$. The agreement between discrete variables was estimated by the $\kappa$ coefficient. ${ }^{11}$ The $\kappa$ coefficient of the question on hand eczema (Q13) was 0.79.
Table 2 Incidences (cases/1000 person-years) of hand eczema in former student bakers and controls with onset at $\geqslant 18 y$ (number of incident cases of hand eczema are in parentheses)

\begin{tabular}{lcc}
\hline & Men & Women \\
\hline Former student bakers: & $16.7(114)$ & $34.4(87)$ \\
$\quad$ When working as baker & $4.5(40)$ & $11.7(54)$ \\
When in other occupations & $5.4(39)$ & $14.1(54)$ \\
School controls & $4.4(32)$ & $11.3(43)$ \\
Population controls & & \\
\hline
\end{tabular}

The reliability of the temporal aspect of the onset of hand eczema (Q14A) was also studied. There were 36 people who had had hand eczema on both occasions. One of them did not answer question $14 \mathrm{~A}$ on the second occasion. Eleven people gave identical answers to question $14 \mathrm{~A}$ on the two occasions, the answers of 12 people differed by 1 year, in six people it differed by 2 years, in three people the difference was three years, in one person the difference was 6 , and in two people 7 years.

\section{DATA ANALYSIS}

Incidences were calculated by the number of new cases of hand eczema per person-years under observation (1961-92). The personyears in bakers and school controls were calculated from the year they left the trade school programme until 1992 or until they developed hand eczema. Population controls contributed with person-years from 18 years of age - that is, the age at which most bakers left school - until 1992 , or until they developed hand eczema. If hand eczema was reported before the age of 18 or if the starting year of the eczema was unknown, the subject was excluded from the incidence study. In bakers, the incidence was calculated separately for time as a baker, and for time in other occupations. Incidence rate ratios were calculated and are referred to as relative risks. 95\% Confidence intervals (95\% CIs) of the relative risk were calculated with the test based method. ${ }^{12}$ Differences between incidences were evaluated with a normal approximation of a binominal test. The $p$ values for differences in prevalences were calculated with the $\chi^{2}$ test. Only $\mathrm{p}$ values $<0.05$ are indicated.

\section{Results}

Of the 2226 former baker students who answered the questionnaire, $1644(73.9 \%)$ had worked as bakers after leaving school, 558 $(25.1 \%)$ had never worked as bakers, and 24 $(1.0 \%)$ did not report their working history. The mean age for men $(n=1280)$ was 31 years, and for women $(n=946) 27$ years.

Hand eczema generally occurred more often among women than men (tables 1 and 2). The cumulative prevalences of hand eczema with onset at the age of $\geqslant 18$ were significantly higher in both men and women among the former baker students who had worked as bakers than in all other groups. The differences between the groups were small and were not significant in the cumulative prevalence with onset of hand eczema at $<15$ years of age (table 1). In male former baker students there was a significantly higher 1 year period prevalence of hand eczema among those who had worked as 
Table 3 Relative risk of hand eczema while working as a baker, $v$ time in other occupations, school and population controls with onset at $\geqslant 18 y$

\begin{tabular}{|c|c|c|c|c|}
\hline \multirow[b]{2}{*}{ Comparison group } & \multicolumn{2}{|l|}{ Men } & \multicolumn{2}{|l|}{ Women } \\
\hline & $\begin{array}{l}\text { Relative } \\
\text { risk }\end{array}$ & $95 \% C I$ & $\begin{array}{l}\text { Relative } \\
\text { risk }\end{array}$ & $95 \% C I$ \\
\hline When in other occupations & 3.7 & 2.6 to 5.3 & 2.9 & 2.3 to 3.8 \\
\hline School controls & 3.1 & 2.2 to 4.4 & 2.4 & 1.9 to 3.2 \\
\hline Population controls & 3.8 & 2.6 to 5.5 & 3.0 & 2.2 to 4.3 \\
\hline
\end{tabular}

Table 4 Incidences (cases/1000 person-years) of hand eczema with onset at $\geqslant 18 y$ relative to reported childhood eczema (Q19) or a family history of atopic eczema (Q21 C) (number of incident cases are within parentheses)

\begin{tabular}{|c|c|c|c|c|}
\hline & \multicolumn{2}{|c|}{ Former student bakers } & \multirow[b]{2}{*}{$\begin{array}{l}\text { School } \\
\text { controls }\end{array}$} & \multirow[b]{2}{*}{$\begin{array}{l}\text { Population } \\
\text { controls }\end{array}$} \\
\hline & $\begin{array}{l}\text { When working } \\
\text { as bakers }\end{array}$ & $\begin{array}{l}\text { When in other } \\
\text { occupations }\end{array}$ & & \\
\hline \multicolumn{5}{|l|}{ Men: } \\
\hline \multicolumn{5}{|c|}{ Childhood eczema: } \\
\hline Yes & $47.1(22)^{\star \star \star}$ & $11.4(7)^{\star \star}$ & $9.7(6)$ & $11.2(7)^{\star \star}$ \\
\hline No & $14.3(88)$ & $4.0(32)$ & $4.8(31)$ & $3.8(25)$ \\
\hline \multicolumn{5}{|c|}{ Family history: } \\
\hline Yes & $23.2(9)$ & $16.1(9)^{\star \star \star}$ & $6.2(3)$ & $6.2(3)$ \\
\hline No & $16.4(91)$ & $3.8(28)$ & $4.7(28)$ & $4.0(24)$ \\
\hline \multicolumn{5}{|l|}{ Women: } \\
\hline \multicolumn{5}{|c|}{ Childhood eczema: } \\
\hline Yes & $71.7(23)^{\star \star \star}$ & $21.9(12)^{\star}$ & $23.4(12)$ & $31.8(16)^{\star \star \star}$ \\
\hline No & $29.0(63)$ & $10.5(41)$ & $12.8(42)$ & $8.1(26)$ \\
\hline \multicolumn{5}{|c|}{ Family history: } \\
\hline Yes & $75.7(19)^{\star \star \star}$ & $24.2(12)^{\star}$ & $14.8(7)$ & $24.2(11)^{\star \star}$ \\
\hline No & $27.9(57)$ & $10.7(39)$ & $14.6(45)$ & $9.5(27)$ \\
\hline \multicolumn{5}{|c|}{${ }^{\star} \mathrm{p}<0.05 ;{ }^{\star \star} \mathrm{p}<0.01 ;{ }^{\star \star \star} \mathrm{p}<0.001$ people with $v$ people without childhood eczema or family history. } \\
\hline \multicolumn{5}{|c|}{$\begin{array}{l}\text { Table } 5 \text { Incidence (cases } 1000 \text { person-years) of hand eczema with onset at } \geqslant 18 \text { y relative } \\
\text { to reported previous onset of hay fever or a family history of hay fever (number of incident } \\
\text { cases are within parentheses) }\end{array}$} \\
\hline & \multicolumn{2}{|c|}{ Former student bakers } & & \\
\hline & $\begin{array}{l}\text { When in } \\
\text { other } \\
\text { occupations }\end{array}$ & $\begin{array}{l}\text { When } \\
\text { working as } \\
\text { bakers }\end{array}$ & $\begin{array}{l}\text { School } \\
\text { controls }\end{array}$ & $\begin{array}{l}\text { Population } \\
\text { controls }\end{array}$ \\
\hline \multicolumn{5}{|l|}{ Men: } \\
\hline \multicolumn{5}{|c|}{ Previous hay fever: } \\
\hline Yes & $25.0(19)$ & $6.3(6)$ & $4.7(5)$ & $9.9(7)^{\star}$ \\
\hline No & $15.7(95)$ & $4.2(34)$ & $5.5(34)$ & $3.8(25)$ \\
\hline \multicolumn{5}{|c|}{ Family history of hay fever: } \\
\hline Yes & $25.5(20)$ & $7.1(6)$ & $10.1(11)^{\star}$ & $7.0(8)$ \\
\hline No & $16.5(88)$ & $3.7(27)$ & $4.7(26)$ & $3.7(21)$ \\
\hline \multicolumn{5}{|l|}{ Women: } \\
\hline \multicolumn{5}{|c|}{ Previous own hay fever: } \\
\hline Yes & $37.9(10)$ & $21.5(10)^{\star}$ & $19.4(9)$ & $26.9(13)^{\star \star \star}$ \\
\hline No & $34.1(77)$ & $10.6(44)$ & $13.4(45)$ & $9.1(30)$ \\
\hline \multicolumn{5}{|c|}{ Family history of hay fever: } \\
\hline Yes & $45.7(20)$ & $18.4(15)$ & $15.4(9)$ & $16.9(12)$ \\
\hline No & $29.1(55)$ & $10.5(36)$ & $13.9(41)$ & $9.6(26)$ \\
\hline
\end{tabular}

${ }^{\star} \mathrm{p}<0.05 ;{ }^{\star *} \mathrm{p}<0.001$ people with $v$ people without hay fever.

a baker, than among those who had not. In female former baker students who had worked as bakers the 1 year prevalence was significantly higher than population controls.

Female bakers had the highest incidences of hand eczema, 34.4 cases $/ 1000$ person-years, whereas male bakers had an incidence of 16.7 (table 2).

For both sexes, the relative risk of hand eczema was significantly greater for work as a baker than for any comparison group (table 3 ). The estimated relative risks were of similar size for the different comparison groups (range 2.4-3.8).

In all, $34 \%$ of all people in the study with hand eczema reported eczema in childhood, this ranged from $29 \%$ among former baker students who had ever worked as bakers to $47 \%$ among population controls. Of all subjects with childhood eczema $44 \%$ had devel-
Table 6 Incidences (cases/1000 person-years) of hand eczema while working as a baker, according to time after start of employment (number of incident cases are within parentheses)

\begin{tabular}{llll}
\hline & \multicolumn{3}{l}{ Years after start of employment } \\
\cline { 2 - 4 } & $\leqslant 1$ & $2-5$ & $\geqslant 6$ \\
\hline Men & $23.4(31)$ & $21.3(50)$ & $10.5(33)$ \\
Women & $43.5(39)$ & $33.7(38)$ & $20.0(10)$ \\
\hline
\end{tabular}

oped hand eczema, the rate being highest among those who had ever worked as bakers $(48 \%)$.

The incidences of hand eczema relative to atopic history are shown in table 4 . People with a history of childhood eczema (affirmative answer to Q19) or a family history of atopic eczema among next of kin (Q21C) had higher incidences than those without such a history. Female bakers reporting childhood eczema had the highest incidences; about 70 cases/ 1000 person-years.

A history of own or family hay fever (affirmative answer to either Q11A or Q21B) increased the incidence of eczema by a factor of about 1.5 (table 5).

A history of childhood eczema was slightly more frequent in both male and female population controls, but the differences were not significantly different from the other groups (table 1).

The highest incidence of hand eczema occurred during the first year of employment as a baker (table 6 ). Even after $\geqslant 6$ years as a baker the incidences were about twice as high as among controls.

Male bakers reported change of job due to hand eczema significantly more often than both control groups and female bakers more often than the population controls (table 1). Of the bakers with hand eczema $31 \%$ had changed job due to the disease, significantly more $(\mathrm{p}<$ $0.01)$ than among the referents $(18 \%)$. Of the bakers who had changed job because of hand eczema, $58 \%$ had a history of childhood eczema.

\section{Discussion}

The study confirms that hand eczema is a common skin disease that affects women more often than men. Some cases are related to occupational exposure and our results designate bakery work as a risk occupation. A history of atopy increases the risk of hand eczema.

\section{ASPECTS OF VALIDITY}

A longitudinal study was chosen instead of a cross sectional design to minimise problems such as selection bias and examination of a survival population. By using a postal questionnaire we were restricted to defining hand eczema as either a complex of skin symptoms or as a self reported diagnosis, the option that we chose. A clinical diagnosis by a dermatologist is often regarded as the gold standard of the diagnosis of hand eczema but only prevalent cases can be verified. The symptoms of hand eczema usually fluctuate with periods free of symptoms. ${ }^{13}$ Thus, if the eczematic 
symptoms disappear, either spontaneously, or for example by change of work, the diagnosis must be based on history or medical records alone.

Selection bias could be operating in the study. A self selection out of bakery school seems most probable and is supported by marginally lower prevalences of childhood eczema and hand eczema before the age of 15 among baker students (table 1). The school controls were originally chosen for the respiratory part of the study and are not ideal for the dermatological aspect as the other food processing trades also entail skin exposure causing hand eczema. Among the school controls a self selection process is indicated of people with a history of skin atopy leaving the trade school, as is the case with bakers (table 1).

Information bias could have been introduced if the bakers tended to describe the onset of hand eczema to time during work as a baker. The high reliability of the question on onset of hand eczema is somewhat against such a time of onset bias. Furthermore, the incidences in bakers when in other occupations were similar to those in the other controls.

The fluctuating natural history of hand eczema makes it difficult to diagnose accurately as not all cases are prevalent at a certain point of time. Smit et $a l^{14}$ made a cross sectional questionnaire study of 207 nurses and found that a self reported diagnosis had a sensitivity of $65 \%$ and a specificity of $93 \%$ compared with a clinical examination by a dermatologist. The 1 year period prevalence was similar between self reported diagnosis $(19.3 \%)$ and clinical evaluations by a dermatologist (18.3\%). In a questionnaire study on male car mechanics, Meding $e t a l^{15}$ used the same questions on hand eczema as in our study. A clinical examination by a dermatologist was performed in 145 people. The specificity of that study was $96 \%$ and the sensitivity $59 \%$.

We have used the history of hay fever as a measure of atopy as the use of biomarkers was considered not to be feasable in this study. For respiratory atopy, self reported hay fever has been compared with Phadiatop screening ${ }^{16}$ or a skin prick test. ${ }^{17}$ The positive predictive values were $37 \%$ and $43 \%$, respectively.

\section{COMPARISONS WITH OTHER STUDIES OF}

INCIDENCE

We found incidences of hand eczema during work as a baker of $16.7 / 1000$ person-years for men and 34.4/1000 for women. The corresponding incidences of Tacke et al were $4.9 / 1000$ person-years in men and 12.0/1000 among women. ${ }^{6}$ In that study the outcome variable was occupational hand eczema diagnosed by an official government physician. If the background incidence of hand eczema of population controls in our study is subtracted from the incidences during bakery work the incidence for male bakers is 12.3 and for female bakers 23.1. The differences in incidences between the two studies can be explained by different diagnostic definitions of hand eczema and data sets obtained in different ways.
Smit and Coenraads ${ }^{18}$ studied the incidence of hand eczema in 371 nurses $(69 \%$ were women) in a retrospective cohort. Hand eczema was defined as a positive answer to a complex of questions on skin symptoms. In all there were 18 incident cases with known time of onset giving an incidence of 42/1000 person-years. The incidence during the first year of employment was 61 . Office employees $(n=115)$ served as controls, one reported case of hand eczema with known time of onset among them gave an incidence of $6 / 1000$ person-years which is in the same order of magnitude as the controls in our study (table 2). A prospective study of hand dermatitis in apprentice hairdressers and nurses ${ }^{19}$ found high incidences, 328/1000 and 145/1000 person-years, respectively. The explanation may be a more generous diagnostic definition of hand dermatitis and a high risk during trade training.

Our study showed the highest incidences during the first year of employment as a baker (table 6). This may indicate that hand eczema is induced quickly in bakers but might also be an effect of a higher skin sensitivity generally at younger ages.

\section{ATOPY}

Childhood eczema has been shown to be a risk factor for adult hand eczema in several studies, ${ }^{20-23}$ and so is previous asthma or hay fever in some studies ${ }^{21}$ but not all. ${ }^{20}$

Skin atopy was in this study defined as either a history of own childhood eczema or atopic eczema among next of kin. Both definitions of atopy had a profound and similar effect on the incidences of hand eczema as shown in table 4 . The frequency of skin atopy among incident cases of hand eczema in bakers in our study was $31 \%$. This contrasts with the $60 \%$ atopic skin diathesis of Tacke et al and probably reflects the difference in defining hand eczema compared with our study.

The impact of childhood eczema and work as a baker on the incidence of hand eczema in men can be estimated. According to table 4 the relative risk for the atopic component in male population controls was $11.2 / 3.8 \sim 3$ and for the exposure component 47.1/11.4 4. The combined relative risk of atopy and exposure is 47.1/4.0 12, which fits well with a multiplicative synergistic effect $(3 \times 4=12)$ of atopy and exposure. An additive model gives a less good fit: $\quad 4.0+(14.3-4.0)+(11.4-4.0)<<47.1$. A similar result was also obtained for women, whereas the effect of a family history seems less pronounced. Respiratory atopy was a weaker predictor and in general increased the incidence of hand eczema by a factor of about 1.5 (table 5).

EXCLUSION OF ATOPIC PEOPLE

It is sometimes proposed that people with atopy should not be employed in risk occupations, such as bakers. The impact of such an exclusion can be estimated if atopy is defined as childhood eczema and its prevalence in men was $12.7 \%$ according to table 1 . If 1000 men from the general population are employed as 
bakers (127 atopic, 873 non-atopic) and are followed up for 10 years, the atopic bakers will accumulate 1270 person years and non-atopic bakers 8730 . Sixty cases of hand eczema will occur among the atopic bakers $(47.1 \times 1.27)$ and 125 cases among non-atopic bakers (14.3×8.73).

If 1000 non-atopic men were employed instead there would have been 143 cases. The preventive effect would be 42 cases (185-143). That means that $42 / 185$ (24\%) of cases of hand eczema among bakers would have been prevented if no atopic people had been employed.

ADVANTAGE OF INCIDENCE STUDY

The study clearly illustrates the advantage of estimating the incidence rather than the prevalence. The ratio of one year period prevalences of hand eczema between bakers and population controls for men was 1.1 (NS) and 1.6 for women $(p<0.05)$. The corresponding ratios for cumulative prevalences of hand eczema with onset after 18 years were 2.2 for men and 1.7 for women (both $\mathrm{p}<0.01$ ) This should be compared with relative risks of incidence of 3-4. If the study had been cross sectional, the prevalence ratios would probably have been even smaller due to selection bias, some of the affected bakers would have changed job because of hand eczema. The longitudinal study design elucidates this problem of job change, nearly one third (31\%) of all incident cases in bakers had changed job.

\section{Conclusions}

Bakers have higher cumulative prevalences and incidences of hand eczema than controls with relative risks of 3-4 in both sexes. This adds epidemiological support to the concept of hand eczema as an occupational disease in bakers. Atopy increases the risk further, possibly in a synergistic manner. Furthermore, bakers change job due to hand eczema more often than controls.
The study was supported by the Swedish Work Environment Fund. Mr Daniel Klein is thanked for his computer assistance and Ms Maria Edvardson and Ms Åsa Fröberg for word processing.

1 Rietschel RL, Fowler FF Jr, eds. Fisher's contact dermatitis, 4th ed. Baltimore: Williams and Wilkins, 1995;577-79.

2 Odom RB, Maibach HI. Contact urticaria: a different contact dermatitis. Cutis 1976;18:672-76.

3 Morren M, Janssens V, Dooms-Goossens A. $\alpha$-Amylase, a flour additive: an important cause of protein contact dermatitis in bakers. F Am Acad Dermatol 1993;29:723-8.

4 Lindemayr H, Drobil M. Contact sensitization to benzoyl peroxide. Contact Dermatitis 1981;7:137-40.

5 Malten KE. Four bakers showing positive patch tests to a number of fragrance materials, which can also be used as flavours. Acta Derm Venereol 1979;(suppl 85):117-21.

6 Tacke J, Schmidt A, Fartasch M, et al. Occupational contact dermatitis in bakers, confectioners and cooks. A

Järvinen KAJ, Pirilä V, Björksten F, et al. Unsuitability of bakery work for a person with atopy: a study of 234 bakery bakery work for a person with atopy: a
workers. Ann Allergy 1979;42:192-5.

8 Pigatto PD, Polenghi MM, Altomare GF. Occupational derPigatto PD, Polenghi MM, Altomare GF. Occupational der-
matitis in bakers: a clue for atopic contact dermatitis. Conmatitis in bakers: a clue for atop

9 Meding B, Swanbeck G. Consequences of having hand

9 eczema. Contact Dermatitis 1990;23:6-14.
0 Brisman SJ, Järvholm BG. Occurrence of self-reported asthma among Swedish bakers. Scand $\mathcal{F}$ Work Environ Health 1995;21:487-93.

11 Cohen J. A coefficient of agreement for nominal scales. Psychological Measures 1960;20:37-46.

12 Miettinen OS. Estimability and estimation in case-referent studies. Am f Epidemiol 1976;103:226-35.

13 Smit HA, Coenraads PJ, Lavrijsen APM, et al. Evaluation of a self-administered questionnaire on hand dermatitis. Contact Dermatitis 1992;26:11-16.

14 Meding B, Swanbeck G. Prevalence of hand eczema in an industrial city. Br $\mathcal{F}$ Dermatol 1987;116:627-34.

15 Meding B, Barregård L, Marcus K. Hand eczema in car mechanics. Contact Dermatitis 1994;30:129-34.

16 Vervloet D, Haddi E, Tafforeau M, et al. Reliability of respiratory symptoms to diagnose atopy. Clin Exp Allergy 1991; ratory sym

17 Charpin D, Hughes B, Mallea M, et al. Seasonal allergic symptoms and their relation to pollen exposure in south-east France. Clin Exp Allergy 1993;23:435-9.

18 Smit HA. Coenraads PJ. A retrospective cohort study on the incidence of hand dermatitis in nurses. Int Arch Occup Environ Health 1993;64:541-4.

19 Smit HA, van Rijssen A, Vandenbroucke JP, et al. Susceptibility to and incidence of hand dermatitis in a cohort of apprentice hairdressers and nurses. Scand $\mathcal{F}$ Work Environ Health 1994;20:113-21.

20 Rystedt I. Hand eczema in patients with history of atopic manifestations in childhood. Acta Derm Venereol Suppl (Stockh) 1985;65:305-12.

21 Meding B, Swanbeck G. Predictive factors for hand eczema. Contact Dermatitis 1990;23:154-61.

22 Nilsson E, Mikaelsson B, Andersson S. Atopy, occupation, and domestic work as risk factors for hand eczema in hospital workers. Contact Dermatitis 1985;13:216-23.

23 Lammintausta K, Kalimo K. Atopy and hand dermatitis in hospital wet work. Contact Dermatitis 1981;7:301-8.50. 